\title{
Moth
}

\section{Sam Watson}

Indigenous Writer, Australia

\begin{abstract}
An Aboriginal woman was walking in a city street. It is suburban Melbourne. She has bought a small axe from the hardware store. To her this axe is a traditional woman's tool. She paid for the axe. She has not done anything wrong. She has broken no laws. She is no threat to herself or to any other person. An armed policeman challenges her. He draws his pistol and shoots her dead.
\end{abstract}

Keywords: Aboriginal Deaths in Custody, Stolen Generations, sovereignty, injustice, Dreaming

eTropic: electronic journal of studies in the tropics publishes new research from arts, humanities, social sciences and allied fields on the variety and interrelatedness of nature, culture, and society in the tropics. Published by James Cook University, a leading research institution on critical issues facing the worlds' Tropics. Free open access, Scopus, Google Scholar, DOAJ, Crossref, Ulrich's, SHERPA/RoMEO, Pandora, ISSN 1448-2940. Creative Commons CC BY 4.0. Articles are free to download, save and reproduce. Citation: to cite this article include Author(s), title, eTropic, volume, issue, year, pages and DOI: http://dx.doi.org/10.25120/etropic.19.1.2020.3725 
\# In recent times there were two major royal commissions into Aboriginal issues. There was the Royal Commission into the Deaths in Custody and there was the Royal Commission into the Stolen Generations.

\# There were inevitable cross overs and links between the two commissions of inquiry. \# The Commission into the Deaths in Custody studied the 99 most recent police murders of Aboriginal people. 65 of those deaths were people who were victims of the Stolen Generations.

\# This Aboriginal woman in Melbourne had been forcibly removed from her mother when she was less than three hours old. The child was taken to Victoria and she was fostered away to a white family. She spent her entire adult life not knowing that she was an Aboriginal child.

\# Finally she is told.

\# Back on her country her Aboriginal birth mother would walk down to the front gate of her home every day at dusk to wait for her baby girl to come home.

\# The woman was able to find out where her family lived.

\# On that day that she finally came home, her family were at the local hospital. Her mother had died that morning.

\# This woman lived in suburban Melbourne. She had problems.

\# The police knew her. They knew that she was no threat.

\# They still shot her down like a crazed dog.

\# No kop was ever charged with any offence over this unlawful killing.

\footnotetext{
A Aboriginal woman was walking in a city street. It is suburban Melbourne. She has bought a small axe from the hardware store. To her this axe is a traditional woman's tool. She paid for the axe. She has not done anything wrong. She has broken no laws. She is no threat to herself or to any other person. An armed policeman challenges her. He draws his pistol and shoots her dead.
}

She went into the market.

Her laughter is as light as the song of a small morning bird.

Her life clock ticks down. 
She only has eleven minutes and fifteen seconds left on this earth.

They will dead her cold.

The murdering British will dead her.

Eternity is closing down for the Aborigines.

No crime.

No court.

No jury.

She was a woman of the desert. She was a visitor in this new land of concrete and bitumen.

She carried the songs and the truth of the desert deep within her own spirit.

She was a woman of the blood.

She was a woman of the Dreaming Line.

She was a woman of two totems - they were the scorpion and the camel.

She knew the sand and the winds.

She knows not this hard, cold country.

She lived her life inside a special palace that was made of dung, glass and broken unmapped pain.

She saw that the Gubs had stolen her Dreaming

The thieves had come in the night.

They had taken her precious gift and they had locked it into a mirror of blind pain.

The song cannot live in that place. It must be free.

Her song is frozen in time.

The land has turned away from her now.

The land can no longer smell her smell.

Desert woman went to a shop and she bought a small axe to free the bird God save the fucking British Queen

Kop jumps from his patrol car.

Screams at her to drop her weapon.

Please. Not weapon. Tool. 
No crime.

No court.

No jury.

Bang. Bloody Murdering British Bullet Number 1.

The bullet tore into her chest. Left of centre.

Central Body Mass.

Bang. Bloody Murdering British Bullet Number 2.

Bullet smashed into the right side of her chest.

Kop in classic combat stance. His eyes locked onto the black woman in front of him. Kop is possessed with blind and terrible hatred.

Bang. Bloody Murdering British Bullet 3.

Lower abdomen. Gut shot.

Air is filled with stink of shit \& blood \& burnt cordite.

Old people screaming.

Small children running. Looking...running...crying.

No crime.

No court.

No jury.

On the nearby ocean a single boat heads up the middle channel into the morning sun.

Bang. Bloody Murdering British Bullet Number 4.

Kop smiles now. Relaxes.

Wet patch on the front of his uniform trousers.

Kop has pissed himself.

$\mathrm{He}$ is death.

Death smells of warm piss and stale nicotine.

It is 1994.

It is St Kilda. City of Melbourne.

Advance Australia Fair.

She falls to the concrete.

She falls into the gaping, blood filled Kunt of the British empire. 
History enfolds her within the great nothing.

Other kops screaming at him.

Holster your weapon. Stand down.

She looks to her bird.

Old man Magpie weeps in the mirrored glass.

But Magpie can do nothing. He has no power now.

She lies upon the stinking concrete.

Her life blood flows wet into the bitumen blackness.

The bloody British law has smashed her life from her.

They smashed her down and they took away her song forever.

Law Versus lore.

Lore lost down.

The Old People sing and they dance amongst the stars

As she walks into the high Dreaming Place on silken feet.

There will be a feast. There will be a gathering.

There will be stories told and there will be laughter.

No more pain now.

Payback will come. Another time. Another place.

Her body is locked within a maze of straight lines.

Therein is the cut. Therein is the mystery.

The British bought the awesome power and the majesty of the straight line onto the ancient land.

The circle of ochre has no power when it is held within a web of cold, hard, straight lines.

That straight line is a fence that cannot be broken. A mountain that can never be climbed and conquered. It cannot be defeated.

It is a power borne out of time and it is greater than the noonday sun.

She was foolish to stand against the straight line of the British man.

God save the queen...

She lay there upon the blood drenched road.

They came and they stared and they turned away. 
They dressed her in that despised garb...

A shroud of bitumen

With thread of wired barb.

God save the fucken British queen.

God rot the British kop.

They will visit him this night...

\# The murder of Daniel Yock

\# The murder of John Pat

\# The murder and rape of the land

\# Black woman now becomes part of the eternal story of the land / the story never dies, when we die in this world - we become a living part of the never ending story of the land

Black man get payback now

Black man rise up now 


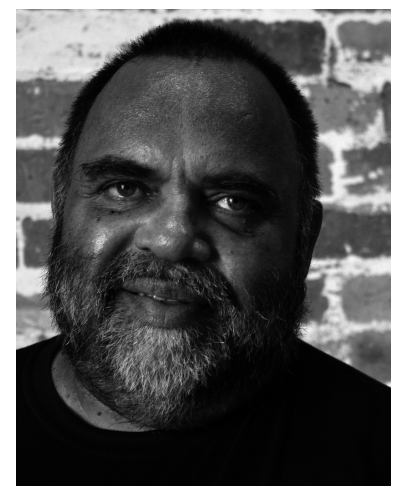

Sam Watson (1952-2019)* was a senior member of the Brisbane indigenous community. He had blood ties to the Wanjiburrah people of the lands around Beenleigh and Mt Jamborine. The Wanjiburrah people are the lawful owners of the Yugenby language. He also had family connections to the Jagara, Yuggerah and Yuggerapull peoples who are the traditional owners of the country on which Brisbane was built. $\mathrm{He}$ also had family and blood line connections to the Biri Gubba people.

His political activism started during his high school days in the 1960s. He protested and marched against the Vietnam War, the White Australia policy and the Apartheid regime of South Africa. In the 1970s he was a member of the staff at the Aboriginal Embassy in Canberra and a co-founder of the Brisbane chapter of the Black Panther Party of Australia. He was also a foundation member of the first wave of indigenous survival services in Brisbane such as the legal service, the medical service, the housing service and other programmes and agencies across the state.

In the 1980s he wrote and published his first award winning novel, The Kadaitcha Sung, which was published by Penguin Books. He also wrote and co-produced two major plays which were presented to critical acclaim by Kooemba Jdarra theatre group and La Boite theatre. The first play was titled "The Mack" and was produced in 1997. The second play, Oodgeroo - Bloodline to Country, was commissioned by the Queensland government as part of the $150^{\text {th }}$ anniversary of the state and produced in 2009. In 1995 he wrote and co-produced his first film, Black Man Down, as one of the ground breaking Sand to Celluloid indigenous short films. Those films were featured in festivals across the global network and screened at the Cannes Festival in 1997.

Sam was a co-founder of the Australian Indigenous Peoples Political Party in 1993. $\mathrm{He}$ also ran for public office himself at local, state and federal elections and advocated for a treaty with the British Crown. Sam Watson served on many local, state and federal committees. He worked on death in custody cases and with Stolen Generation peoples. He was committed to the struggle to assert his rights as a sovereign Aboriginal man.

In his artistic work Watson explored traditional indigenous cultural themes and tensions. He asserted his own identity as a traditional owner and custodian of the lands across south east Queensland and he celebrated his close affinity and bond with the spiritual strengths of country.

* Permission to publish the photo of Sam Watson has been granted by his family. 